\title{
Distribution, feeding and ecomorphology of four species of Auchenipteridae (Teleostei: Siluriformes) in Eastern Amazonia, Brazil
}

\author{
Tiago M. S. Freitas' Luciano F. A. Montag² \& Ronaldo B. Barthem³ $^{3}$
}

\begin{abstract}
1. Faculdade de Ciências Naturais, Campus Universitário do Marajó-Breves, Universidade Federal do Pará, 68.800-000 Breves, PA, Brazil. (freitastms@gmail.com) 2. Laboratório de Ecologia e Conservação, Instituto de Ciências Biológicas, Universidade Federal do Pará, 66.075-1 10 Belém, PA, Brazil.

3. Coordenação de Zoologia, Museu Paraense Emílio Goeldi, 66077-830 Belém, PA, Brazil.
\end{abstract}

Received 28 April 2016

Accepted 11 October 2016

DOI: $10.1590 / 1678-4766 e 2017008$

\begin{abstract}
Fish exhibit morphological, physiological and behavioral specializations which enable them to display different ways to explore the environments and resources. Thus, the aim of this study was to verify how four Auchenipteridae species differ in the distribution, feeding habits and morphological traits: Auchenipterichthys longimanus (Günther, 1864), Auchenipterus nuchalis (Spix \& Agassiz, 1829), Tatia intermedia (Steindachner, 1877) and Trachelyopterus galeatus (Linnaeus, 1766). This study was conducted in rivers and bays of the Anapú Basin, Pará State (Brazil), where these species are abundant. Specimens were collected using gillnets, and after caught the stomachs were removed for the contents analyzes. Eighteen morphometric measurements from ten adult specimens of each species were taken, combined into fifteen ecomorphological attributes. The species distribution showed that $A$. longimanus was restricted to rivers, while the others were exclusively caught in the bays. All four species had their diet composed of allochthonous insects, but $A$. longimanus also exhibited a great frugivorous habit. The most important ecomorphological attributes were relative to the consumption of larger food items (for A. longimanus and T. galeatus) and to the longer swimming capacity (for A. longimanus and T. intermedia). These morphological differences and the trophic diversity presented in this study highlighted some important information about how ecomorphological similar species behave and share resources, which may play a significant role on the coexistence of these species in the Anapú Basin.
\end{abstract}

KEYWORDS. Fish, morphology, diet, adaptation.

RESUMO. Distribuição, alimentação e ecomorfologia de quarto espécies de Auchenipteridae (Teleostei: Siluriformes) da Amazônia Oriental, Brasil. Peixes apresentam especializações morfológicas, fisiológicas e comportamentais que permite a exploração do ambiente e dos recursos de diferentes maneiras. Sendo assim, o objetivo deste trabalho foi verificar como quatro espécies de peixes da Família Auchenipteridae diferem quanto à distribuição, alimentação e traços morfológicos: Auchenipterichthys longimanus (Günther, 1864), Auchenipterus nuchalis (Spix \& Agassiz, 1829), Tatia intermedia (Steindachner, 1877) e Trachelyopterus galeatus (Linnaeus, 1766). Esse estudo foi realizado nos rios e baías da Bacia do Rio Anapú, Estado do Pará (Brasil), onde essas espécies são abundantes. Os espécimes foram coletados com rede de espera, e após a captura os estômagos foram removidos para a análise dos conteúdos. Dezoito medidas morfométricas foram aferidas de dez indivíduos adultos de cada espécie, posteriormente combinadas em quinze atributos ecomorfológicos. A distribuição das espécies evidenciou que $A$. longimanus foi restrita aos ambientes de rios, enquanto as demais foram exclusivamente capturadas nas baías. Todas as quatro espécies tiveram a dieta composta por insetos alóctones, mas $A$. longimanus também apresentou hábito frugívoro. Os mais importantes atributos ecomorfológicos foram relativos ao consumo de itens alimentares grandes (para $A$. longimanus e $T$. galeatus) e a maior capacidade natatória (para A. longimanus e T. intermedia). Essas diferenças morfológicas e a diversidade trófica apresentada neste estudo elucidam importantes informações sobre como espécies ecomorfologicamente semelhantes compartilham os recursos, desempenhando um papel significativo na coexistência dessas espécies na bacia do Rio Anapú.

PALAVRAS-CHAVE. Peixe, morfologia, dieta, adaptação.

Fish have different morphological, physiological and behavioral specializations that enable them to show a great plasticity in the resource and habitat usage (LowEMcConnell, 1987). The knowledge of fish diet is an important way to understand the relationships between the species and the environment in which they live, considering both biological and ecological aspects (MOREIRA \& ZUANON, 2002; RAMíREZ et al., 2015).

Several studies focusing on feeding biology have been conducted in natural communities of freshwater fish in Brazil, through a detailed investigation of the feeding habits as an alternative way to analyze the use of habitat by different species (BAKER et al., 2014). Indirect methods, as ecomorphology, were also used for the description of the feeding and environmental tactics of the species (WINEMILLER, 1991; SeVEro-Neto et al., 2015).

Ecomorphology is included in the evolutionary biology, and is used to describe relationships between morphology and ecology by studying the relationship between body shape and organisms' ecological features (GATZ JR., 1979; WATSON \& BALON, 1984; WINEMILLER, 1991). It is based on the idea that the morphological differences between species are caused by the pressure of different types of environments (BEAumord \& PETRERE JR., 1994). Thus, 
significant relationships between morphology and ecology can occur due to the phylogenetic proximity. Phylogenetic information within ecomorphological analyses is the only way to objectively identify cases of morphological and adaptive convergence and divergence (CASATTI \& CASTRO, 2006). Essentially, this integration allows the better comprehension of evolutionary patterns within the communities (PERESNeto, 1999).

Regarding the Family Auchenipteridae (Siluriformes), available data on ecology and biology addresses only a few species (Moresco \& Bemvenuti, 2005; SAntos, 2005; Freitas et al. 2011; MaIA et al., 2013; SAntos et al., 2013). The Auchenipteridae species are endemic to the Neotropics and belong to two subfamilies: Centromochlinae and Auchenipterinae (BIRINDELLI, 2014).

This study was conducted in rivers of Caxiuanã National Forest in the Anapú Basin, Pará State (Brazil), where four Auchenipteridae species were abundant (MoNTAG et al., 2013): Auchenipterichthys longimanus (Günther, 1864), Auchenipterus nuchalis (Spix \& Agassiz, 1829), Trachelyopterus galeatus (Linnaeus, 1766) (belong to the Auchenipterinae group) and Tatia intermedia (Steindachner, 1877) (Centromochlinae group). The Auchenipteridae species are generalized as carnivorous, preying mainly insects as well plankton and fish (FERRARIS JR., 2003). Thus, the aim of this study was to verify the distribution, feeding habits and morphological traits of these species, in an attempt to verify how closely related species differ in the use of resources.

\section{MATERIAL AND METHODS}

Study area. Caxiuanã National Forest (FLONA of Caxiuanã) is located downstream from the Anapu River, between Tocantins and Xingu rivers, eastern Amazonia, in the municipalities of Melgaço and Portel (State of Pará,
Brazil) (Fig. 1). The main water systems of the Caxiuanã region are rivers and bays. The rivers are narrower and deeper than the bays, with vegetation limited to the river edge and sporadic floating macrophyte banks. The bays are marked by areas that have a greater width and lower depth with a high frequency of large floating macrophyte banks, mainly Eicchornia spp. and Cyperacea (MonTAG et al., 2008). The bays are "rias fluviais" formed by fractures that have been enlarged by sediment deposited into their mouths, forming natural underwater dams which transform them into "lakes". Additionally, a complex network of rivers and streams create an extremely heterogeneous environment (COSTA et al., 2002).

Data sampling. Specimens were collected in March/ April 2004 (high-water period) and October/November 2004 (low-water period), 40 days per period, using gill nets of 80 $\mathrm{m}$ long, with different mesh sizes. The nets were set up at midnight and removed in the next morning, between $07 \mathrm{~h}$ and $08 \mathrm{~h}$. The sites where the nets were set up were selected with the help of a local fisherman, who pointed out the best areas for possible catches. Individuals collected were fixed in 10\% formaldehyde, later preserved in 70\% ethanol, identified and deposited in the Ichthyological collection of Museu Paraense Emílio Goeldi (MPEG), Belém, Pará, under serial number MPEG 8575; 8576; 8577; 8579; 8586; 8634; 8635; 8637; $8678 ; 8687 ; 8702 ; 8705 ; 8708 ; 8722 ; 8724 ; 8725 ; 8737$; $8755 ; 8760 ; 8764 ; 8769 ; 8804 ; 8846 ; 8853 ; 8868 ; 8872$; $8874 ; 8888 ; 8891 ; 8909 ; 8911 ; 8943 ; 8972 ; 9365$.

Feeding analyzes. The stomachs were removed and the contents of each stomach were examined in the laboratory of Ichthyology of MPEG, using Petri dishes, a precision scale and a stereoscope to identify each food item. The identification of food items was performed at the lowest possible level using specific literature and specialist assistance. The items had their frequency of occurrence (FO\%; HYSLOP, 1980) and mass percentage (M\%; HYNES,

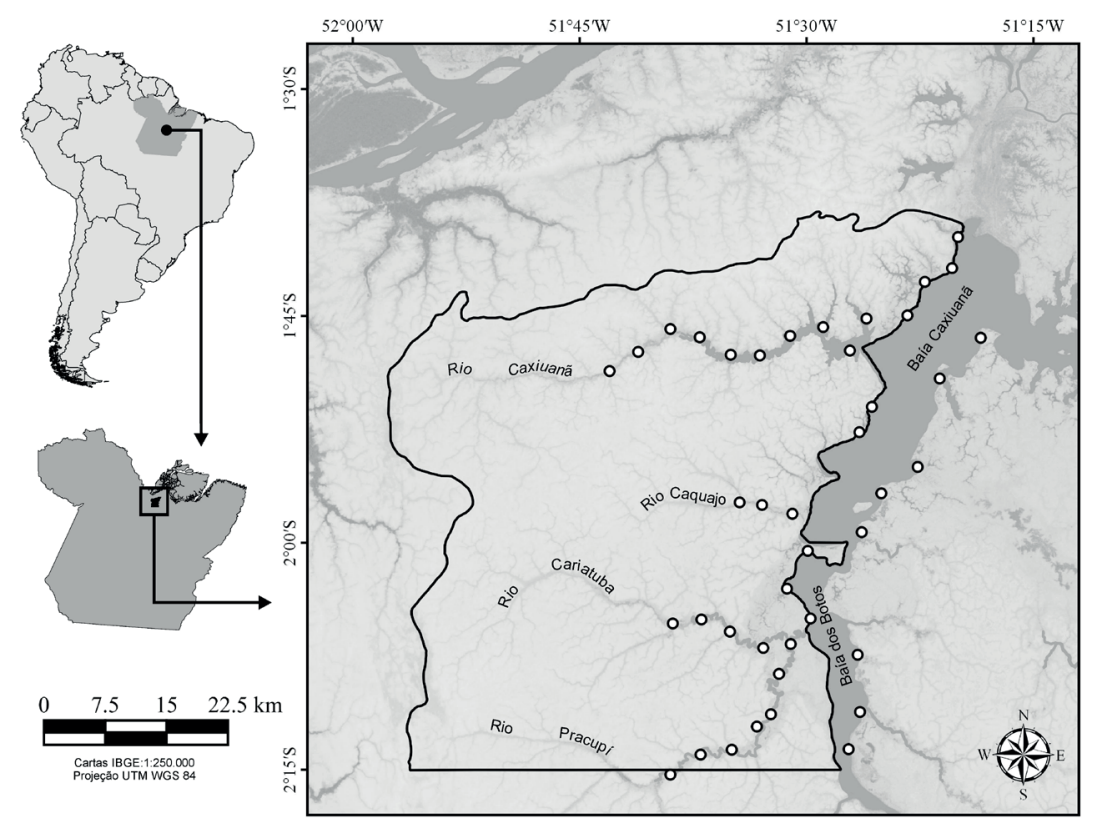

Fig. 1. Location of the Caxiuanã National Forest, municipalities of Melgaço and Portel, State of Pará, showing the ichthyofauna sampling sites. 
1950) calculated. These two parameters (FO\% and $\mathrm{M} \%$ ) were combined into the Alimentary Index (Ai\%; modified from KAWAKAMI \& VAZZOLER, 1980), which finally attributes the importance of the items in the diet. Empty stomachs were not quantified. The $\mathrm{Ai} \%$ was calculated by the equation $\mathrm{Ai} \%$ $=\left(\mathrm{FO} \% * \mathrm{M} \% / \sum \mathrm{FO} \% * \mathrm{M} \%\right) * 100$ and the empty stomachs were not included in the analysis. This method attempts to characterize the dominance of a particular food item in the examined stomachs from a quantitative scale that estimates the relative mass of each item.

Ecomorphological analyzes. Eighteen morphometric measurements from ten adult specimens of each species were taken (Tab. I), using a digital caliper for measurements and parchment paper for surface area. For the last, Scion Image 4.0.2 software was used to obtain values of body area (BA), pectoral fin area (PFA) and caudal fin area (CFA).

The morphometric measurements were used to obtain fifteen ecomorphological attributes, interpreted as indicators of the types of lifestyle or as adaptations to different habitats and were associated with the swimming ability, type of environment and trophic plasticity: 1) relative length of the caudal peduncle $(\mathrm{RLCP}=\mathrm{CPL} / \mathrm{SL})$ : indicates that longer peduncle, better swimmer it will be, including the benthic species living in environments with high hydrodynamics (WATSON \& BALON, 1984); 2) compression index of the caudal peduncle $(\mathrm{CICP}=\mathrm{CPA} / \mathrm{CPL})$ : compressed peduncles indicates fishes with slow swimming, low maneuverability and low capacity for rapid bursts as the bodies height increases between different species (GATZ JR., 1979); 3 ) relative area of the pectoral fin $(\mathrm{RAPF}=\mathrm{PFA} / \mathrm{BA})$ : higher values may indicate slow swimmers, that use their pectoral fins for braking or performing maneuvers, or fish that live in running water and use their fins to deflect the flow, therefore stabilizing their position in the substrate (ALEXANDER, 1974); 4) relative area of the caudal fin $(\mathrm{RACF}=\mathrm{CFA} / \mathrm{BA})$ : larger caudal fins indicate rapid bursts (BALON et al., 1986); 5) aspect ratio of the pectoral fin $(\mathrm{ARPF}=\mathrm{PFL} / \mathrm{PFW})$ : higher values indicate long and narrow fins, present in species that swim over long distances (KEAST \& WEBB, 1966); 6) aspect ratio of the caudal fin $\left(\mathrm{ARCF}=\left((\mathrm{CFW})^{2} / \mathrm{CFA}\right)\right.$ : higher values indicate fishes with continuous and active swimming (GATZ JR., 1979); 7) relative position of the eyes $(\mathrm{RPE}=\mathrm{EH} / \mathrm{HH})$ : benthic fishes have eyes dorsally located, while nektonic species have lateral eyes (GATZ JR., 1979); 8) compression index (CI=BH/ $\mathrm{BW})$ : higher values may indicate laterally compressed fishes that inhabit lentic environment (WATSON \& BALON, 1984); 9) relative height $(\mathrm{RH}=\mathrm{BH} / \mathrm{SL})$ : an attribute related to the ability to develop vertical movement, being inversely related to highly hydrodynamic (lotic) environments (GATZ JR., 1979); 10) ventral flattening index (VFI=ABH/BH): lower values indicate species associated to rapids, permitting the fish to maintain their position without swimming (MAHON, 1984); 11) relative head length $(\mathrm{RHL}=\mathrm{HL} / \mathrm{SL})$ : higher values suggest predator species of relatively large prey (WATSON \& BALON, 1984); 12) relative mouth width ( $\mathrm{RMW}=\mathrm{MW} /$ $\mathrm{SL}$ ); higher values also suggest predator species of relatively large prey (GATZ JR., 1979); 13) relative area of mouth ( $\left.\mathrm{RAM}=\mathrm{MW}^{*} \mathrm{MH} / \mathrm{BA}\right)$ : higher values indicate larger food items in the fish diet (A. C. Beaumord, unpubl. data); 14) relative height of mouth ( $\mathrm{RHM}=\mathrm{HM} / \mathrm{SL})$ : attribute related to the size of the food resource, and also to the hydrodynamic morphology (WATSON \& BALON, 1984); 15) mouth aspect ratio $(\mathrm{MAR}=\mathrm{MH} / \mathrm{MW})$ : attribute related to the shape of the food resource which higher values indicate fishes with narrow mouth, but large aperture, suggesting piscivorous habit (A. C. Beaumord, unpubl. data).

Variation on ecomorphological attributes between species was analyzed through a principal component analysis (PCA), which relevant axes were identified by the brokenstick model (JACKSON, 1993). The loadings higher than 0.8 were used for explanations.

Tab. I. Eighteen biometric measurements measured for the ten adult specimens of Auchenipterichthys longimanus (Günther, 1864), Auchenipterus nuchalis (Spix \& Agassiz, 1829), Tatia intermedia (Steindachner, 1877) and Trachelyopterus galeatus (Linnaeus, 1766).

\begin{tabular}{lcl}
\hline Measurements & Acronyms & Descriptions \\
\hline Standard Length & SL & Distance from tip of snout to end of caudal peduncle \\
Body Height & BH & Largest dorso-ventral distance perpendicular to largest body axis \\
Body Width & BW & Largest body width \\
Average Body Height & ABH & Distance from vent to line that cuts body from mouth to tail \\
Caudal Peduncle Length & CPL & Distance from end of anal fin to beginning of caudal fin \\
Caudal Peduncle Widthw & CPW & Width of peduncle at its mid-point \\
Caudal Peduncle Height & CPH & Height of peduncle at its mid-point \\
Head Length & HL & Distance from tip of snout to end of operculum \\
Head Height & HH & Distance from ventral part and dorsal part of head in the region of the eyes \\
Eye Height & EH & Distance from center of eye to lower jaw \\
Mouth Width & MW & Distance between lateral parts of totally open mouth without distention of muscles \\
Mouth Height & MH & Distance between lips of open mouth without distention of muscles \\
Pectoral Fin Length & PFL & Distance between the base of the fin and its extremity \\
Pectoral Fin Width & PFW & Largest width of fin on axis perpendicular to the axis of the length of the fin when totally open \\
Caudal Fin Width & CFW & Distance between the two extremities of the fin when totally distended \\
Body Area & BA & Area of body plus caudal fin \\
Pectoral Fin Area & PFA & Area of pectoral fin when totally distended \\
Caudal Fin Area & CFA & Area of caudal fin when totally distended \\
\hline
\end{tabular}




\section{RESULTS}

Distribution. A total of 621 specimens were captured, 395 A. longimanus (mean SL $11.5 \mathrm{~cm} \pm 1.8 \mathrm{~cm}$ ), $145 \mathrm{~T}$. intermedia $(7.1 \mathrm{~cm} \pm 0.8 \mathrm{~cm}), 53 \mathrm{~A}$. nuchalis $(10.4 \mathrm{~cm} \pm$ $0.6 \mathrm{~cm})$ and $28 \mathrm{~T}$. galeatus $(12.5 \mathrm{~cm} \pm 1.8 \mathrm{~cm})$. The species A. longimanus was restricted to rivers; specimens of $\mathrm{T}$. intermedia were preferentially caught in the bays, but two individuals were caught in rivers. A. nuchalis and T. galeatus were captured exclusively in the bays.

Feeding. We analyzed a total of 410 stomachs, 224 from $A$. longimanus, 127 from $T$. Intermedia, 38 from $A$. nuchalis and 21 from $T$. galeatus. The Alimentary index (Ai\%) values are presented in Table II. The diet of $A$. longimanus showed the greatest diversity of food items, 21 items in total. The most important items were allochthonous insects $(\mathrm{Ai} \%=52.94)$ and seeds $(\mathrm{Ai} \%=45.64)$.

Three items composed the $\operatorname{diet}$ of $A$. nuchalis, but terrestrial insects represented $99.89 \%$. Nine food items were found in stomachs of $T$. intermedia of which the allochtonous insects were the most important $(\mathrm{Ai} \%=99.79)$. The species T. galeatus had a total of eight food items, and also showed terrestrial insects as the most important $(\mathrm{Ai} \%=69.64 \%)$, followed by aquatic crustacean $(\mathrm{Ai} \%=11.65)$.

Ecomorphology. The first two axis of the PCA had broken-stick eigenvalues significantly larger than random, and explained $61.2 \%$ of the variance in the ecomorphological data (Fig. 2). Axis 1 accounted $37.4 \%$ of the variation and axis 2 computed $23.8 \%$. The first axis segregated species that were influenced by relative mouth width (RMW; eigenvector $=0.96)$ and relative head length (RHL; eigenvectors $=0.84$ ).

The second axis also revealed intraspecific variation within species, and it was influenced by a positive correlation of aspect ratio of the pectoral fin (ARPF; 0.81 ) and by a negative correlation of relative height of mouth (RHM; -0.82). The result of the principal component analysis, applied to

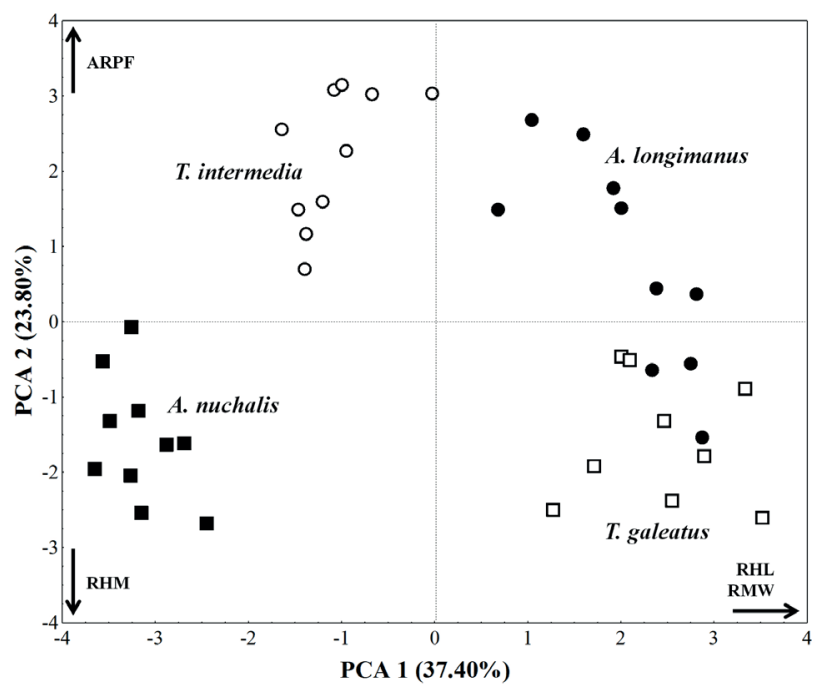

Fig. 2. Ordination diagram of the first two PCAaxes for the 15 ecomorphological attributes of four auchenipterid species: $(\bullet)$ Auchenipterichthys longimanus (Günther, 1864), (-) Auchenipterus nuchalis (Spix \& Agassiz, 1829), (०) Tatia intermedia (Steindachner, 1877) and (口) Trachelyopterus galeatus (Linnaeus, 1766). The attributes that most influenced this distribution are shown: RMW, relative mouth width; RHL, relative head length; ARPF, aspect ratio of the pectoral fin; RHM, relative height of mouth.

the matrix of 15 ecomorphological attributes is shown in Table III.

\section{DISCUSSION}

Understanding how ecomorphological traits showed by species in relation to environmental gradients is a basic premise for prediction of species distributions through a macroecology observation (SEVERo-Neto et al., 2015). In the present study, we described the distribution, diet and ecomorphology for four species from Auchenipteridae in the lower Anapú River (Eastern Amazonia). The taxonomic

Tab. II. Alimentary index (Ai\%) of food items consumed by the four Auchenipteridae species from the Caxiuanã National Forest, Pará, Brazil.

\begin{tabular}{|c|c|c|c|c|}
\hline Food items & A. longimanus & A. nuchalis & T. intermedia & T. galeatus \\
\hline Algae & $<0.01$ & & & \\
\hline Annelida (Oligochaeta) & $<0.01$ & & $<0.01$ & \\
\hline Araneae & $<0.01$ & & $<0.01$ & \\
\hline Chilopoda & $<0.01$ & & & \\
\hline Crustacea (allochthonous) & $<0.01$ & & $<0.01$ & $<0.01$ \\
\hline Crustacea (autochthonous) & $<0.01$ & & & 11.65 \\
\hline Detritus & $<0.01$ & & & \\
\hline Diplopoda & $<0.01$ & & $<0.01$ & 8.18 \\
\hline Insecta (allochthonous) & 52.94 & 99.89 & 99.79 & 69.64 \\
\hline Insecta (autochthonous larvae) & $<0.01$ & 0.00 & $<0.01$ & \\
\hline Mammalia (fur) & $<0.01$ & & & \\
\hline Nematoda & $<0.01$ & & & \\
\hline Opiliones & $<0.01$ & & $<0.01$ & \\
\hline Osteichthyes & $<0.01$ & & & $<0.01$ \\
\hline Osteichthyes (scales) & $<0.01$ & & & 2.85 \\
\hline Plantae (branch/root) & 0.91 & & $<0.01$ & 1.06 \\
\hline Plantae (seeds) & 45.65 & & & 5.87 \\
\hline Platyhelminthes (Tubellaria) & $<0.01$ & & $<0.01$ & \\
\hline Scorpiones & $<0.01$ & & & \\
\hline Squamata (Snake skin) & $<0.01$ & & & \\
\hline Vertebrate Fragments & $<0.01$ & 0.00 & & \\
\hline
\end{tabular}


Tab III. Mean (M) and standard deviation (SD) values for the 15 ecomorphological attributes calculated for four Auchenipteridae species from the Caxiuanã National Forest, Pará, Brazil. CI, compression index; RH, relative height; RLCP, relative length of the caudal peduncle; CICD, compression index of the caudal peduncle; VFI, ventral flattening index; RAPF, relative area of the Pectoral Fin, ARPF, Aspect Ratio of the Pectoral Fin; RACF, relative area of the caudal fin; ARCF, aspect ratio of the caudal fin, RPE, relative position of the eyes; RHL, relative head length; RMW, relative mouth width; RHM, relative height of mouth; MAR, mouth aspect ratio; RAM, relative area of mouth.

\begin{tabular}{|c|c|c|c|c|c|c|c|c|c|c|}
\hline \multirow{2}{*}{ Ecomorphological atributes } & \multicolumn{2}{|c|}{ A. longimanus } & \multicolumn{2}{|c|}{ T. intermedia } & \multicolumn{2}{|c|}{ A. nuchalis } & \multicolumn{2}{|c|}{ T. galeatus } & \multicolumn{2}{|c|}{ PCAAxis } \\
\hline & M & SD & $\mathrm{M}$ & SD & M & SD & M & SD & 1 & 2 \\
\hline $\mathrm{CI}$ & 1.261 & 0.14 & 1.3 & 0.11 & 2.446 & 0.38 & 1.285 & 0.09 & -0.748 & -0.462 \\
\hline RH & 0.287 & 0.05 & 0.207 & 0.01 & 0.197 & 0.01 & 0.284 & 0.03 & 0.788 & -0.116 \\
\hline RLCP & 0.097 & 0.02 & 0.158 & 0.03 & 0.12 & 0.02 & 0.075 & 0.01 & -0.557 & 0.479 \\
\hline CICD & 3.512 & 1.26 & 2.724 & 0.36 & 2.549 & 0.35 & 3.713 & 0.47 & 0.643 & -0.147 \\
\hline VFI & 0.628 & 0.07 & 0.569 & 0.05 & 0.619 & 0.08 & 0.487 & 0.11 & -0.304 & 0.192 \\
\hline RAPF & 0.047 & 0.01 & 0.012 & 0.01 & 0.023 & 0 & 0.046 & 0.01 & 0.712 & -0.262 \\
\hline ARPF & 5.254 & 2.1 & 5.681 & 1.76 & 3.232 & 0.8 & 2.915 & 0.83 & -0.018 & 0.811 \\
\hline RACF & 0.128 & 0.03 & 0.189 & 0.03 & 0.12 & 0.02 & 0.123 & 0.02 & -0.147 & 0.707 \\
\hline $\mathrm{ARCF}$ & 1.721 & 0.7 & 1.522 & 0.39 & 2.166 & 0.37 & 1.525 & 0.4 & -0.321 & -0.518 \\
\hline RPE & 0.398 & 0.11 & 0.517 & 0.1 & 0.683 & 0.09 & 0.511 & 0.14 & -0.673 & -0.332 \\
\hline RHL & 0.261 & 0.03 & 0.216 & 0.02 & 0.203 & 0.01 & 0.27 & 0.03 & 0.844 & -0.216 \\
\hline RMW & 0.131 & 0.01 & 1.06 & 0.01 & 0.059 & 0.01 & 0.131 & 0.01 & 0.961 & 0.127 \\
\hline RHM & 0.037 & 0.01 & 0.04 & 0.01 & 0.053 & 0.01 & 0.056 & 0.01 & -0.062 & -0.823 \\
\hline MAR & 0.283 & 0.05 & 0.404 & 0.08 & 0.899 & 0.09 & 0.431 & 0.07 & -0.773 & -0.56 \\
\hline RAM & 0.018 & 0.01 & 0.195 & 0 & 0.016 & 0 & 0.029 & 0.01 & 0.541 & -0.635 \\
\hline Eigenvalue & & & & & & & & & 5.61 & 3.58 \\
\hline$\%$ of Variance & & & & & & & & & 37.40 & 23.83 \\
\hline Broken-stick Eingenvalue & & & & & & & & & 3.32 & 2.32 \\
\hline
\end{tabular}

proximity between these species is an important question and could generate more competition, since members of Auchenipteridae inhabit very similar niches (FERRARIS JR., 2003): nocturnal species, hiding during the day in rock crevices and submerged branches and trees, which probably involved several similar adaptations in morphology and behavior.

Montag et al. (2013) observed that $A$. longimanus and T. intermedia shown great abundance in the aquatic systems of Caxiaunã National Forest (Eastern Amazon, Brazil), but A. longimanus is unique to rivers and $T$. intermedia inhabits preferably in the bays. This segregated distribution may have played an important role in their local existence, and caused a reduction in the pressure of interspecific competition for food and territory, since they are ecomorphologically similar, inhabit marginal areas and feed on allochtonous items. Hugueny \& Pouilly (1999) suggested that the availability of food may be one of the factors that prevent the establishment of relationships between diet and morphology when the study is restricted to species belonging to the same trophic category.

Regarding the trophic ecology of auchenipterids, the feeding habits of the four analyzed species are similar to those found for the same genera, such as insectivorous/ frugivorous for Auchenipterichthys (FrEITAS et al., 2011), and insectivorous for Auchenipterus (MÉRONA et al., 2008), Tatia (RAMíREZ et al., 2015) and Trachelyopterus (XIMENES et al., 2011).

According to the ecomorphological hypothesis proposed, the attributes may reflect important aspects of their ecology, such as habit and adaptation to different resources (BALON et al., 1986). Thus, based on the principal component analysis, and evidenced by the higher values of the attributes RMW and RHL, we found that $A$. longimanus and T. galeatus tend to feed on larger items, such as seeds and aquatic crustaceans, respectively.

Higher values of ARPF for A. longimanus and T. intermedia may reveal the longer swimming capacity between the other analyzed species. Despite this attribute was originally related to migrations (KEAST \& WEBB, 1966), this swimming activity may vary in amplitude, which can be defined as the extent of the displacement and/or the regularity of which it occurs among fish species. There are migrants that travel long distances and others that travel only a few meters. There are those that move laterally, limiting their migration to stretches of small tributaries for breeding and/ or feeding purposes (CAPELETI \& PETRERE JR., 2006). Here we consider that these two species have larger displacement capacity during their periods of activity.

On the other hand, lower values of ARPF for A. nuchalis and T. galeatus attribute a low capacity of performing extended moving, and could assume that these species inhabit more structured environments. BREDA et al. (2005) confirms this environmental preference at least for T. galeatus, indicating that the morphology of the caudal fin of this species allow it to perform upward and downward movements of the posterior part of the body, providing improved performance in environments of high complexity.

Despite the close phylogenetic relationship between the analyzes species, and based on distribution, feeding habits and ecomorphological traits, we observed a smooth dissimilarity within A. nuchalis, A. longimanus, T. intermedia and T. galeatus in the lower Anapú River. However, the set of characteristics presented in this study highlighted some important information about how ecomorphological similar species behave and share resources. We believe that morphological adaptations and trophic diversity play a significant role on the coexistence of species in the Amazonian fish assemblages. 
Acknowledgements. This work was supported by funds from Fundo Nacional do Meio Ambiente (FNMA) and Conselho Nacional de Pesquisa e Desenvolvimento (CNPq). We thank Gilberto N. Salvador for creating the map used in this paper. We are also grateful to Mr. Benedito Brazão for assistance in fieldwork.

\section{REFERENCES}

Alexander, R. McN. 1974. Functional design in fishes. London, Huchinson. 160p.

Baker, R.; Buckland, A. \& Sheaves, M. 2014. Fish gut content analysis: robust measures of diet composition. Fish and Fisheries 15:170-177.

Balon, E. K.; Crawford, S. S. \& LeleK, A. 1986. Fish communities of the upper Danube River (Germany, Austria) prior to the new Rhein-MainDonau connection. Environmental Biology of Fishes 15:243-271.

Beaumord, A. C. \& Petrere Jr., M. 1994. As comunidades de peixes do Rio Manso, Chapada dos Guimarães, MT. Acta Biologica de Venezuelica 15(2):21-35.

BirINDELLI, J. L. O. 2014. Phylogenetic relationships of the South American Doradoidea (Ostariophysi: Siluriformes). Neotropical Ichthyology 12:451-564.

Breda, L.; Oliveira, E. F. \& Goulart, E. 2005. Ecomorfologia de locomoção de peixes com enfoque para espécies neotropicais. Acta Scientiarum, Biological Sciences 27(4):371-381.

Capeleti, A. R. \& Petrere JR., M. 2006. Migration of the curimbatá Prochilodus lineatus (Valenciennes, 1836) (Pisces, Prochilodontidae) at the waterfall "Cachoeira de Emas" of the Mogi-Guaçu River - São Paulo, Brazil. Brazilian Journal of Biology 66(2):651-659.

Casatti, L. \& Castro, R. M. C. 2006. Testing the ecomorphological hypothesis in a headwaters riffles fish assemblages of the rio São Francisco, southeastern Brazil. Neotropical Ichthyology 4(2):203-214.

Costa, M. L.; Kern, D. C.; Behling, H. \& Borges, M. S. 2002. Geologia. In: LisBOA, P. L. B. ed. Caxiuanã: populações tradicionais, meio físico e diversidade biológica. Belém, Museu Paraense Emílio Goeldi, p.179-205.

FERRARIS JR., C. J. 2003. Family Auchenipteridae. In: ReIs, R. E.; KULLANDER, S. O. \& Ferraris Jr., C. J. eds. Check List of the Freshewater Fishes of South and Central America. Porto Alegre, Edipucrs, p.473-485.

Freitas, T. M. S.; Almeida, V. H. C.; Valente, R. M. \& Montag, L. F. A. 2011. Feeding ecology of Auchenipterichthys longimanus (Siluriformes: Auchenipteridae) in a riparian flooded forest of Eastern Amazonia, Brazil. Neotropical Ichthyology 9:629-636.

GatZ JR., A. J. 1979. Community organization in fishes as indicated by morphological features. Ecology 60:711-718.

Hugueny, B. \& Pouilly, M. 1999. Morphological correlates of diet in an assemblage of West African freshwater fishes. Journal of Fish Biology 54:1310-1325.

Hynes, H. B. N. 1950. The food of fresh water Sticklebacks (Gasterosteus aculeatus and Pygosteus pungitius), with a review of methods used in studies of the fishes. Journal of Animal Ecology 19:36-58.

HYSLOP, E. J. 1980. Stomach contents analysis: a review of methods and their application. Journal of Fish Biology 17:411-429.

JACKSON, D. A. 1993. Stopping rules in principal components analysis: a comparison of heuristical and statistical approaches. Ecology 74(8):2204-2214.

KaWAKami, E. \& VAzzoler, G. 1980. Método gráfico e estimativa de índice alimentar aplicado no estudo de alimentação de peixes. Boletim do Instituto Oceanografico 29(2):205-207.
Keast, A. \& WebB, D. 1966. Mouth and body form relative to feeding ecology in the fish fauna of small lake Opinicon, Ontario. Journal of the Fisheries Research Board of Canada 23:1845-1874.

Lowe-McConnell, R. H. 1987. Ecological studies in tropical fish communities. Cambridge, Cambridge University Press. 400p.

MAHON, R. 1984. Divergent structure in fish taxocenes of north temperate streams. Canadian Journal of Fisheries and Aquatic Sciences 41:330-350.

Maia, R. M.; Artioli, L. G. S. \& HartZ, S. M. 2013. Diet and reproductive dynamics of Trachelyopterus lucenai (Siluriformes: Auchenipteridae) in subtropical coastal lagoons in southern Brazil. Zoologia 30(3):255-265.

Mérona, B.; Hugueny, B.; Tejerina-Garro, F. L. \& Gautheret, E. 2008. Diet-morphology relationship in a fish assemblage from a mediumsized river of French Guiana: the effect of species taxonomic proximity. Aquatic Living Resources 21:171-184.

Montag, L. F. A.; Freitas, T. M. S.; Benone, N. L.; Ferreira, C. P.; Wosiacki, W. B. \& Barthem, R. B. 2013. Ecologia de peixes em um "quase-lago" da Amazônia Oriental. In: LisBOA, P. L. B. ed. Caxiuanã: paraíso ainda preservado. Belém, Museu Paraense Emílio Goeldi, p.577-593.

Montag, L. F. A.; Freitas, T. M. S.; Wosiacki, W. B. \& Barthem, R. B. 2008. Os peixes da Floresta Nacional de Caxiuanã (municípios de Melgaço e Portel, Pará - Brasil). Boletim do Museu Paraense Emílio Goeldi, Ciências Naturais 3(1):11-34.

Moreira, S. S. \& Zuanon, J. 2002. Dieta de Retroculus lapidifer (Perciformes: Cichilidae), um peixe reofílico do Rio Araguaia, Estado de Tocantins, Brasil. Acta Amazonica 32(4):691-705.

Moresco, A. \& Bemvenuti, M. A. 2005. Morphologic features and feeding analysis of the black catfish Trachelyopterus lucenai Bertoletti, Pezzi da Silva \& Pereira, 1995 (Siluriformes, Auchenipteridae). Acta Limnologica Brasiliensis 17(1):37-44.

Peres-Neto, P. R. 1999. Alguns métodos e estudos em ecomorfologia de peixes de riachos. In: Caramaschi, E. P.; Mazzoni, R. \& Peres-Neto, P. R. eds. Ecologia de Peixes de Riachos. vol. VI. Rio de Janeiro, Oecologia Brasiliensis, p. 209-236.

Ramírez, F.; DAVEnPort, T. L. \& MoJiCA, J. I. 2015. Dietary-morphological relationships of nineteen fish species from an Amazonian terra firme blackwater stream in Colombia. Limnologica 52:89-102.

Santos, A. C. A. 2005. Ecologia alimentar do molé, Trachelyopterus galeatus Linnaeus, 1766 (Siluriformes, Auchenipteridae), em trechos inferiores dos rios Santo Antônio e São José (Chapada Diamantina, Bahia). Sitientibus, Série Ciências Biológicas 5(2):93-98.

Santos, H. B.; Arantes, F. P.; Sampaio, E. V. \& Sato, Y. 2013. Artificial reproduction and reproductive parameters of the internally inseminated driftwood catfish Trachelyopterus galeatus (Siluriformes: Auchenipteridae). Ichthyological Research 60(2):142-148.

Severo-Neto, F; Teresa, F. B. \& Froehlich, O. 2015. Ecomorphology and diet reflect the spatial segregation between two Siluriformes species inhabiting a stream of the Bodoquena Plateau, in Central Brazil. Iheringia, Série Zoologia 105(1):62-68.

WATSON, D. J. \& BALON, E. K. 1984. Ecomorphological analysis of fish taxocenes in rainforest streams of northern Borneo. Journal of Fish Biology 25:371-384.

WiNEMILLER, K. O. 1991. Ecomorphological diversification in lowland freshwater fish assemblages from five biotic regions. Ecological Monographs 61:343-365.

Ximenes, L. Q. L.; Mateus, L. A. F. \& Penha, J. M. P. 2011. Variação temporal e espacial na composição de guildas alimentares da ictiofauna em lagoas marginais do Rio Cuiabá, Pantanal Norte. Biota Neotropica 11(1):205-216. 